\title{
LEARNING: THE ROLE OF AESTHETICS IN EDUCATION
}

\author{
J. Adu-Agyem and M. Enti \\ Department of General Art Studies, \\ Kwame Nkrumah University of Science and Technology, Kumasi, Ghana
}

\begin{abstract}
The study is qualitative and it drew on the historical research method, descriptive and case study methods to examine the link between learning, art, and the creative nature of children. Its aim is to transmit the value of art in enhancing creativity through aesthetics in children and consequently enhance their learning. Thus, the study through the use of document analysis (analyzing the art works of the children), what the children had to say about their works, interviews and the observation tools throws light on how effective learning could be when taken in the context of art to boost creativity in children; and also enable the teacher to identify some activities that could or should be incorporated in the teaching of children. Since creativity is increasingly gaining recognition as a human characteristic that can be (and should be) developed through education, there is the need to make conscious efforts to develop children's creativity and learning through art education. This way, teachers do not necessarily produce children who would by all means become artists but rather creative children who can transfer the skills they have learnt through art to other subject areas and in effect to all other facets of their lives.
\end{abstract}

Keywords: Child, Art, Creativity, Aesthetics, Education

\section{INTRODUCTION}

Art and music are familiar examples of creativity, but creative thought emerges in almost all facets of life - from the way a parent soothes a crying child to the methods a scientist uses to discover a cure for a disease (DeBord, 1997). There has been much research into the link between the expressive arts (art, music, dance, and dramatics) and creativity; but this is not to deny the role of crea- tivity in other areas such as Science, Mathematics and Business.

A look at today's schools, reveal that they are concerned (as they rightly should be) with teaching literacy. However, literacy must not be limited to the written word. It should also embrace the symbol systems of the arts. If the concept of literacy is defined too narrowly as referring to just the systems of language, mathematics and sci-

160 Journal of Science and Technology, Vol. 29, No. 1, April, 2009 
ence, children will not be equipped with the breadth of symbolic tools they need to fully represent, express and communicate the full spectrum of life.

What then constitutes a good education? Lowenfeld and Brittain (1970) define education as "the cultivation of expression in an organized manner. That is, it is the organization of words to make verbal communication, the organization of numbers or symbols to develop mathematical thinking, and the organization of images to make the arts" (p32). It can be implied here then, that education has to do with developing aesthetic behaviour. Aesthetics, an aspect of art education, here is explained to mean an active perceptual process; the process of organizing, thinking, feeling, and perceiving into and expression that communicate these thoughts and feelings to someone else (Lowenfeld \& Brittain, 1970; Maquet, 1986).

Getting employed is the ultimate when one gets an education. Children should know how to read, write and compute so that they can get employed. Few would argue with that. Considering the demands that young people will face tomorrow in this technological society, the need for literacy in English Language, Mathematics, Science and History is critical. But being educated or learned does not simply mean the accrual or accumulation of knowledge. To think of it that way is to seriously narrow its scope. However, learning also implies an understanding of how this knowledge can be used. The ability to use one's senses (touching, seeing, hearing, smelling and tasting) freely and creatively can help our learning to be effective, and this can be achieved through art education (Lowenfeld \& Brittain, 1970). This is what good education entails; knowledge to be able to perceive (with the senses), process and translate raw knowledge or data into useable information for oneself as well as communicate it to someone else.

Thus, the objective of employability should not allow us to overlook the importance of the arts and their consequence on the mind and spirit of every child since the arts serve as a vehicle for developmental learning for children of all ages and abilities and offer essential opportunities for creative expression, problem-solving, and social development (Potter, 2007). However, as Lowenfeld and Brittain (1970) noted about four decades ago, it is still a fact that schools have done little to educate these senses that are our only avenue to learning. It is with this background that this paper puts across that an education in Art is the way forward to educate the senses, and as a result enhance the individual's learning abilities to learn creatively and efficiently.

\section{MATERIALS AND METHODS}

The qualitative research approach was adopted for the study with special emphasis on historical research and document analysis. This paper reviewed and analyzed some studies that have been done on the importance of art, creativity and learning. The study is also part of an ongoing project which has observed some of the effects on children's learning that non-exposure to art in any form brings as well as some of the results art interventions provide for children for a period of one year. The sample size of children taken from four basic schools in Kumasi was 153. Some teachers in these schools were also interviewed about the performance of the children. Thus, the paper is a blend of a review of some studies that have been done on the above mentioned fields buttressed with some observations that were made in the sampled schools.

\section{RESULTS AND DISCUSSION}

Art's Use in other Subjects in the Primary School

Art as a subject was noted not to be part of the subjects taught in some of the primary schools mainly the Public Schools (government or aban schools as they are sometimes known). However, in the teaching of other subjects such as Environmental or Social Studies, Religious and Moral Education, English Grammar, and Mathematics, art was incorporated to aid the children to better 
understand. For instance in an Environmental Studies class in one of the schools, where the topic of "How Food is Produced" was treated, the class was made to copy an illustration on the chalk board that depicted the stage of food production that was discussed in that lesson. The drawings of two boys that illustrate the concept of food production are shown in Figs 1 and 2. Learning thus became fun.

The concept of food production that was explained with illustration buttresses a study done in the Autonomous University of Yucatan. That study revealed that education is an ideal meeting point of Art and Science which share common roots since they both employ creative thinking. Some undergraduate students learnt genetics through art by making contemporary artwork about DNA as well as creating personal visions of it from genetic data using scientific and artistic knowledge. Thus, applying art-science exercises in the education of science at the different levels can aid learners to better comprehend basic scientific concepts while developing creative thinking at the same time (Cepeda, 2007). In other words, Art creates a seamless connection between motivation, instruction, assessment and practical application, leading to deeper understanding.

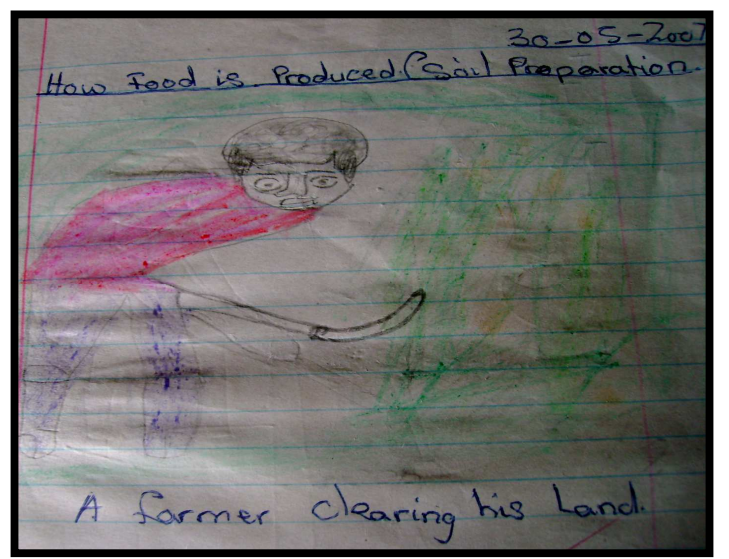

Figure 1: 'The clearing stage of food production' drawn by an 8 year old boy

\section{Art makes Learning easier}

It was also discovered that children who had opportunities to create art found learning easier. This is because art employs concepts such as divergent thinking (a concept that accepts many different or opposing views) as such the thinking faculties of children are stimulated and awakened. No one answer is correct in art. There can be more than one correct answer; all in an effort to encourage divergent thinking and problem solving skills. Bates (2000) adds that on the whole, art education has the power to develop multiple forms of literacy, encourage multiple solutions to problems and promote multiple forms of intelligence.

de Cueller (2005) adds that "the century has transformed the entire planet from a finite world of certainties to an infinite world of questioning and doubt. So if ever there was a need to stimulate creative imagination and initiative on the part of individuals, communities and whole societies, that time is now. The notion of creativity can no longer be restricted to the arts; it must be applied across the full spectrum of human problem solving".

\section{Art and Aesthetic education}

What should be noted is that the arts convey messages by social release and cultural symbols sheathed in aesthetically pleasing ways. Flood

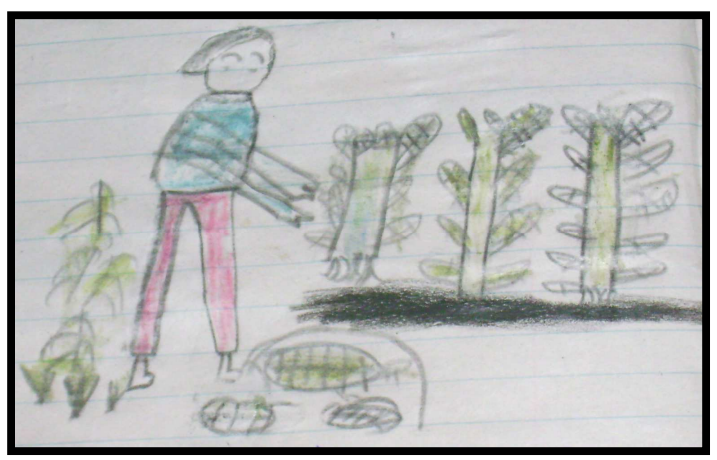

Figure 2: 'The harvesting stage of food production' depicted by a 10 year old girl

162 Journal of Science and Technology, Vol. 29, No. 1, April, 2009 
and Bamford (2007) explain that the tragedy of schooling presently, is that it mostly ignores this kind of literacy. Children are expected to acquire written literacy and numeracy, since these are valued to be vital to their employability and adulthood. However, very little importance is afforded aesthetic or artistic literacy. They add that although, future eras will be dominated by multidimensional communication systems yet schools do not see this as essential in the curriculum; since the prevailing attitude is that the arts are elitist or reserved for the elite; nice, but not really necessary.

Nonetheless, Margaret Naumberg shares her view on the link between the artistic literacy and the unconscious needs and desires that underlie a child's behavior in school. She further states that:

To the child experiencing stress under the rigours of growing up and in the confines of the school, the visual arts could serve as a form of release. Art could, if used intelligently, contribute to the mental health of the child by giving him an opportunity to alleviate those tensions and communicate those meanings that he could not articulate in discursive language. Art in the schools could be a type of therapy, a preventive medicine that contributes to the psychological comfort of the child (Pappas, 1970 p21).

At the core of this is the fact that Art provides an outlet for the child to pour out his frustrations, when he cannot memorize the multiplication table, or he had no food to eat before coming to school but relies on the School Feeding Programme (Personal Conversation, 2007) as well as acting as a shield for emotional crisis when he does not get the needed attention especially parental care. Art helps the children in these situations to have emotional release and subsequently makes them emotionally sound people. For instance, when asked to draw anything they wanted, some of the children drew pictures that expressed their experiences and how they felt (e.g. hurt, sadness, anger, and happiness) in some situations they were involved in (see Figs $3-5$ ). The boy who made Fig 3 explained that he was beaten for something he did not do, whiles the girl who made Fig 4 remembered the nice time she had during her birthday party.

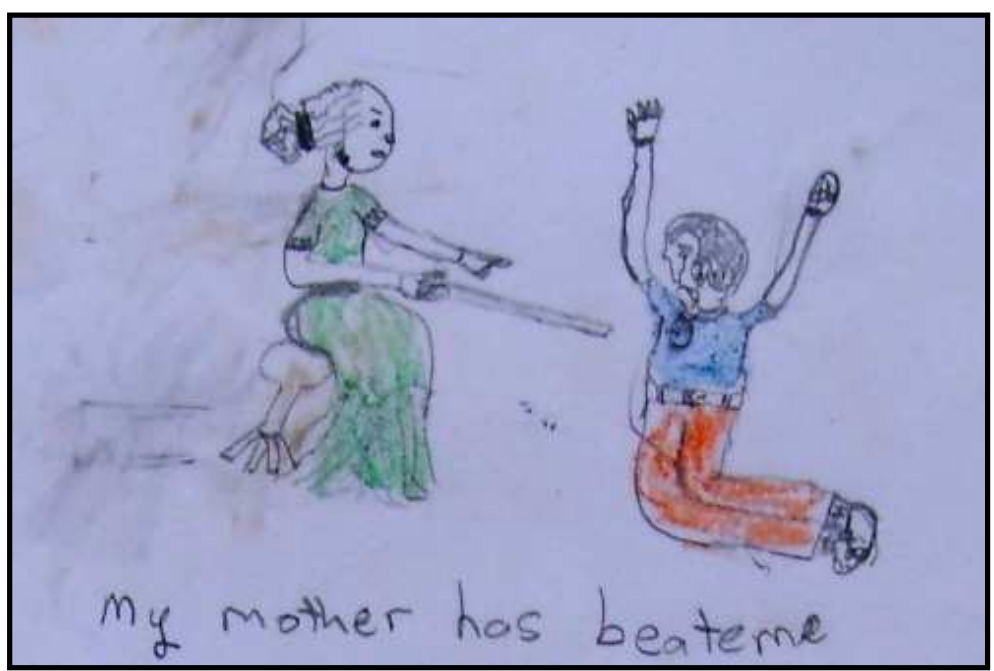

Fig 3: A drawing by an 8 year old boy who explained that he was very sad when beaten 


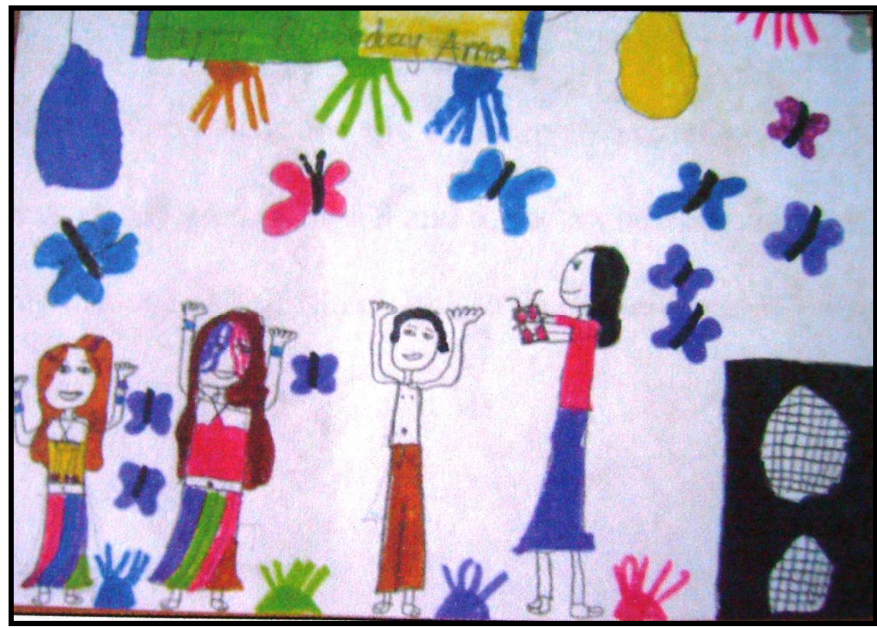

Fig 4: A drawing by a 7 year old girl that showed the party held for her on her $6^{\text {th }}$ birthday

The boy who drew Fig 5 is currently in an orphanage. He confided that he used to help his mother cook before being brought to the orphanage. In view of this he made this picture (Fig 5) after five years of being in the orphanage to show how much he missed his mother. He even attributed his favourite game of playing football to his father whom according to the Director of the orphanage he does not even know.

In a way, what was not convenient for the children to verbalize, especially with feelings of sadness, and loneliness as depicted in Figs 3 and 5, the art sessions made it possible and easy for the children to convey (Jacobs, 2002; Malchiodi, 2001). Their learning attitudes in the class also showed some significant improvement.

\section{Aesthetics as a source of Education}

Aesthetics means "perception" in Greek (Schirrmacher, 1998). Aesthetics includes art and other expressive arts like music and dance; however, it goes beyond these and includes such things as an awareness and appreciation of the natural beauty found in nature and in one's surroundings, being connected with one's experiences and linking knowing and feeling, that is the cognitive and the affective.

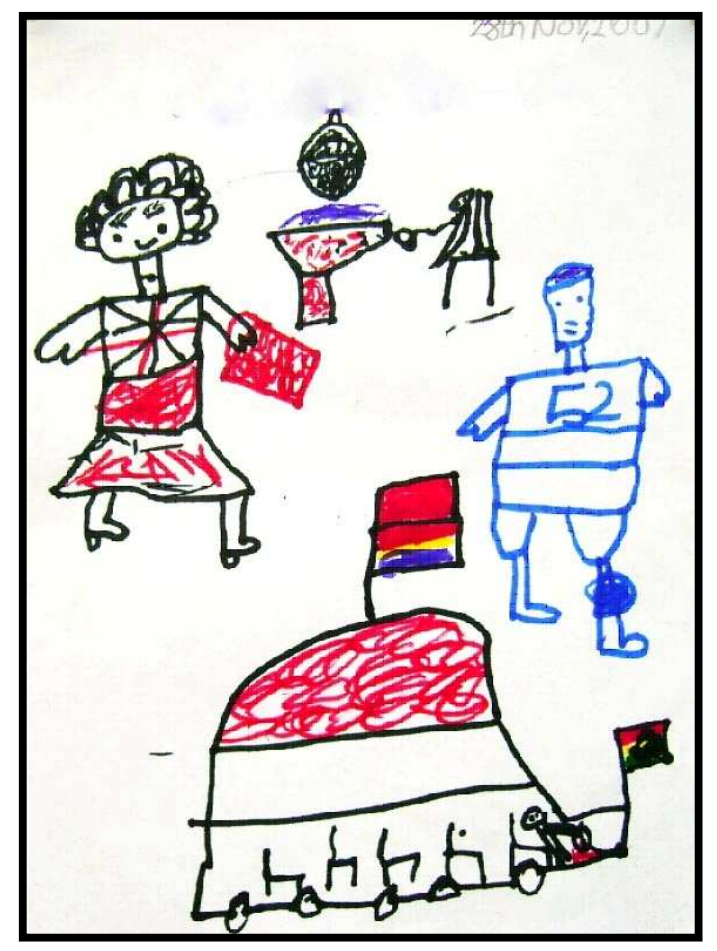

Fig 5: A ten year old showed his parent he misses

164 Journal of Science and Technology, Vol. 29, No. 1, April, 2009 
Schirrmacher (1998) offers some reasons for the importance of aesthetic education. First, aesthetic education provides for all facets of the child's development. Research has revealed that Art has a major role to play in the education and total development of children. For instance, Lekettey (1995) quotes Read who indicates that child art ensures the intellectual, psychomotor and affective development of the child. Thus, Art educates the child holistically since the intellectual, psychomotor and affective skills which the child acquires (in Art) sum up his entire personality.

Secondly, it is believed that children who marvel at beauty in the world around them will be able to appreciate the beauty of letters, words, numbers, stories, poems, formulae, books and people of different cultures.

Besides, children with aesthetic sense will grow into adults who know and value good design and can apply this as wise consumers in choosing furnishings, clothing, entertainment as well as on a broader level in planning activities, constructing cities, and trying to solve problems such as pollution, poverty and epidemics.

Moreover, aesthetic experiences such as admiring the linear design of a storey building, watching the gentle sway of leaves, listening as rain drops on the roof top, or savouring the aroma of some nkontomire and salted fish sauce; all foster concept development. Swartz (2003) explains concept formation as the process of integrating a series of features that group together to form a class of ideas or objects. Developmentally, a younger child might define a bird as any object that flies in the air. The first time this child sees an airplane in flight, he may point to the sky and say, "Bird!" The observant parent or caregiver might correct the child by saying, "No that's not an airplane. Birds fly but they have feathers. Airplanes fly but they don't have feathers." Thus, concept maps may also prove to be an invaluable aid in concept formation.

Apart from enhancing concept formation in children by providing them with concrete experi- ences, hands-on experience, concept maps (sometimes referred to as concept webs or semantic maps) are diagrams that illustrate the critical attributes of concepts. For example, the name of a concept could be written in the centre of a blank page with a circle around it; for example bird. The five critical attributes of that concept could each be written in smaller circles around the concept, connected by a line; example; two-legged, wings, a beak, body covered with feathers, and lays eggs. Students would then have a mental image of that concept to carry into any discussion or test.

Learning environments must be created with these in mind to suit theses experiences since learning environments are more effective when they facilitate encounters between intelligences of children and materials.

The Teacher's Role in encouraging Aesthetic education to foster learning

It has become usual for teachers not to like the creative child who is also aesthetically literate since he normally bends the rule to suit himself. It is rather the sweet conforming child who is considered the better one by the teacher and hence rewards him to the drawback of the creative noncompliant child. This attitude must be eschewed in order to enhance creativity and aesthetic awareness in children.

The teacher must also create an atmosphere that encourages creativity as well as aesthetic development in the classroom. That is, the teacher must prepare conditions or settings that enhance creative and aesthetic development. A child must be allowed to deviate from group activity if the need arises. Denying the desire to make such diversion by treating the child as disruptive and taking disciplinary action can be frustrating to the child and might even make him withdraw from participating in class activities thereby affecting learning output.

Moreover, since children generally learn by imitation, teachers can invest time and become aesthetically responsive in order to act as models for 
their learners. For instance, the teacher can help the learners reflect an appreciation of colour and colour harmony on clothes or shoes that are worn; "you are wearing a green pair of shoes. The colour hue matches my leather bag; and the fresh leaves on that big tree have this same shade of green."

Furthermore, the teacher has to identify with each child and know his weakness in order to be of help to him. For instance, during the art sessions with one of the schools, several children drew small figures on the papers that were given them (see Figs 6 and 7).

Interactions with some children who drew small figures based on some series of works showed that some of the children were shy and withdrawn. Some also viewed the blank pieces of pa-

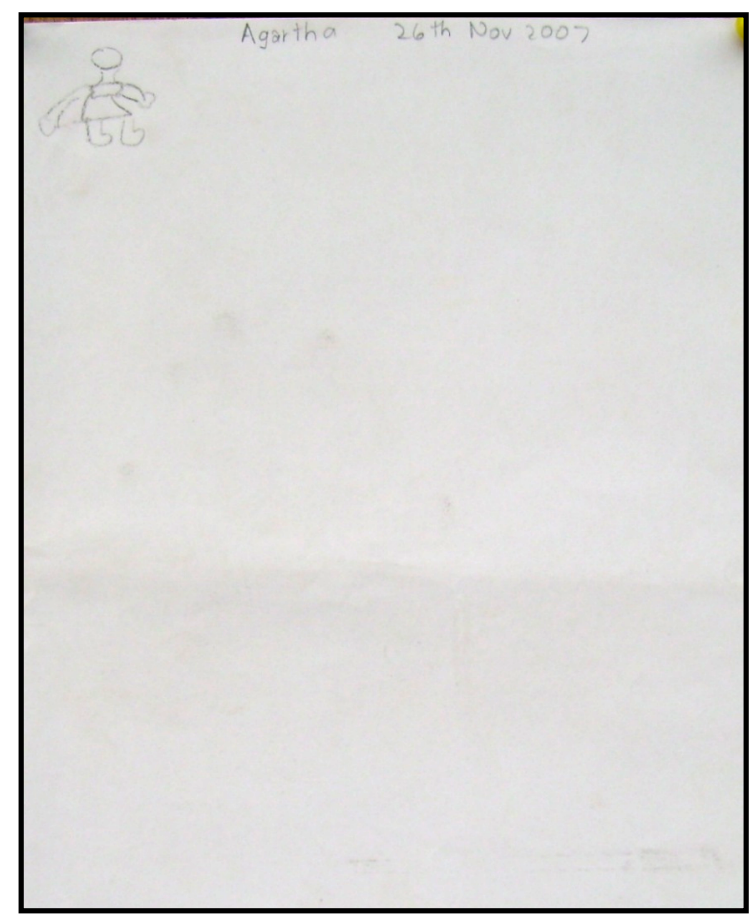

Fig 6 per as threats; but identifying with them and interacting with some of them took away part of the 'barriers' they had set up in meeting strangers (like the researchers). They felt much at ease and volunteered information about the drawings they had made, opening them up to more learning opportunities.

Art educators need to be reminded that they have a fundamental obligation to provide the fuel that will ignite the mind, spark the aspirations, and illuminate the total being of the child. The arts, especially in the area of aesthetics can often serve as that fuel. They are the ways one applies his imagination, thought and feeling through a range of "languages" to illuminate life in all its mystery, misery, delight, pity and wonder. They are basic

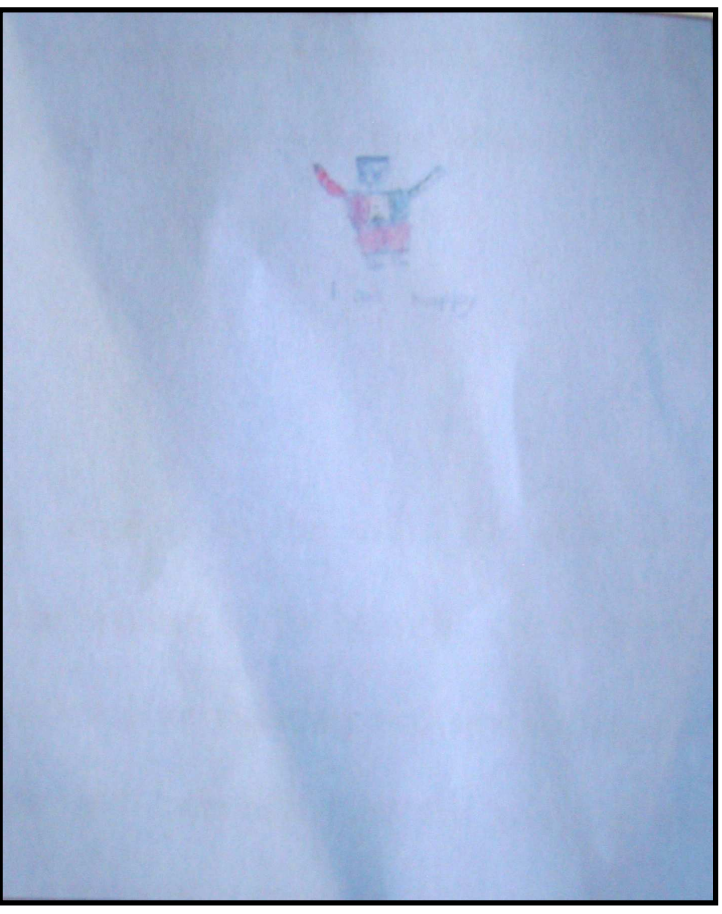

Fig 7

Fig 6 and 7: Drawings that show small sizes of small figures in relation to the paper size

166 Journal of Science and Technology, Vol. 29, No. 1, April, 2009 
to helping one engage more significantly with his inner self and the world around him. As the child first engages one ability, others are enabled, too, to emerge.

\section{CONCLUSION}

No one can impose aesthetic knowledge; it must come from the child himself. However, acquiring this knowledge needs reinforcement and the teacher is the best person to provide the environmental conditions that will make the art experience an exciting and rewarding one. It is through identifying with the child, with his needs and interests that the teacher can best understand the needs and desires of each child. This is especially true for the child who may not turn naturally to art as a form of expression; for this may be the child who most needs the art experience.

Parents on the other hand, can do well to encourage their children to pursue creative activities since art is entwined with a child's aesthetic and creative growth and is a requirement of all spheres of life.

It is apparent that there is no shortage of advice for early childhood workers on how to foster children's creative development and enhance their learning in the process. What seems to be lacking however, is well-documented, practical examples of successful initiatives by early childhood practitioners in Ghana. Thus, the following is noteworthy.

- The government in line with formally recognizing pre-school (kindergarten) as relevant because of the crucial role it plays in the formative years of the child can set up action research projects for early childhood practitioners. These projects will research into dayto-day problems teachers face whiles dealing with children in the areas of creativity and provide findings that will be applied in the classroom to enhance learning in children. Those practitioners with an interest in fostering aesthetic development and enhancing creativity could then volunteer to participate.

- Individuals with expertise in art, education and psychology could also present participants of the action research projects with briefings on research and practice likely to boost aspects of creativity. These will be done in order to train the participants and equip them with knowledge they would need in handling children.

- There should be evaluation of the programme from time to time to ensure that teachers are helping to enhance aesthetic knowledge and creativity to better equip children to translate and apply the school knowledge they acquire to their daily lives in order to become useful citizens of Ghana.

- Besides, teachers will have to respect the uniqueness of individual children and value them. They should try and find something beautiful and unique in each child and praise it. When children are appreciated this way, they learn to appreciate others thus fostering positive self concepts which in the long run help them learn better.

\section{REFERENCES}

Bates, J. (2000). Becoming an Art teacher. Wadsworth, U.S.A

Curzon, L.B. (1990). Teaching in Further Education: An Outline of Principle and Practice, $4^{\text {th }}$ (Ed). Trowbridge, Great Britain: Redwood Books, pp 27 - 45

Dickinson, D. (ed): Creating the future. Perspectives on Educational Change In: Charles Fowler (2002): Every Child Needs The Arts [http://www.newhorizons.org], (accessed 2007 November 15)

DeBord, K. (1997). Child Development: Creativity in Young Children. North Carolina Coop- 
erative Extension Service [http://www. ces.ncsu.edu/depts/fcs/human/pubs/ fcs470.pdf], (accessed 2008 January 8).

de Cueller, P.J. (2005). Our creative diversity: Report of the World commission on culture and Development. Paris: UNESCO

Flood, A. and Bamford, A. (2007). Manipulation, simulation, stimulation: the role of art education in the digital age. International Journal of Education through Art, 3 (2): 91-101.

Hammer, E.F. (1980). The Clinical Application of Projective Drawing. USA: Charles. C. Thomas pp 195-200

Jacobs, J. A. (2002). Drawing is a catharsis for children. Department of Psychology, Copyright 2008, Missouri Western State University [http://clearinghouse.missouriwestern. edu/manuscripts/363.asp], (accessed 2008 January 28)

Lekettey, B. L. (1995). A Manual on Some Creative Activities for Pre-school. Unpublished MA Thesis, Department of General Art Studies, KNUST, Kumasi, Ghana

Lowenfeld, V. and Brittain, W. L. (1970). Creative and Mental Growth (5 ${ }^{\text {th }}$ Ed). London: Collier-Macmillan Limited, The Macmillan Company, pp 21- 43.

Malchiodi, C. A. (2001). Using Drawing as Intervention with Traumatized Children. TRAUMA AND LOSS: Research and Interventions, 1(1): [http://www.tlcinst.org/ drawingintervention.html], (accessed 2007 October 12)

Maquet, J. (1986). The Aesthetic Experience. New Haven, London: Yale Univ. Press
Ministry of Education (2002). Meeting the Challenges of Education in the twenty first century, (Committee Report). Accra, Ghana.

Patton, M. Q. (1990). Qualitative evaluation and research methods, 2nd ed. Newbury Park, CA: Sage Publications [http://www.gifted. uconn.edu/siegle/research/Samples/ purposivesampling.htm], (accessed 2008, April 10)

Pappas, G. (1970). Concepts in Art and Education: An Anthology of Current Issues. New York: The Macmillan Company

Potter, J. (2007). Draw Me A Story, Dance Me A Poem: Integrating Expressive Arts Fosters Emergent Literacy [http://www.wiu.edu/ thecenter/articles/draw2.html], (accessed 2007 October 17)

Schirrmacher, R. (1998). Art and Creative Development for Young Children. $\left(3^{\text {rd }}\right.$ Ed). U.S.A.: Delmar Publishers pp 178-181

Sharp, C. (2001). Developing Young Children's Creativity through the Arts: What has Research have to offer? Paper presented to an invitational Seminar, Chadwick Street Recreation Center, London, 14 February 2001 [http://www. nfer.ac.uk/research/papers/ creativity.pdf], (accessed 2005 March 25)

Swartz, J. (2003). Concept Formation and Problem Solving: Understanding and Managing Two Key Components of Higher Order Cognition [http://allkindsofminds.org/ Articles.aspx], (accessed 2008 January 15)

168 Journal of Science and Technology, Vol. 29, No. 1, April, 2009 